\title{
The teachers' effort in inheriting values originated from the Bugis-Makassar tribe
}

\author{
Abdul Azis, Universitas Pendidikan Indonesia, Indonesia, abdul.azis@upi.edu, ORCID: 0000-0001-5645- \\ 8545 \\ Kokom Komalasari, Universitas Pendidikan Indonesia, Indonesia, kokom@upi.edu, ORCID: 0000-0001- \\ 6370-5639 \\ Sapriya, Universitas Pendidikan Indonesia, Indonesia, sapriya@upi.edu, ORCID: 0000-0003-1814-4806 \\ Rahmat, Universitas Pendidikan Indonesia, Indonesia, rahmat003@upi.edu, ORCID: 0000-0001-8719-0668
}

\begin{abstract}
This study aimed to reveal the teachers' activities in passing on pacce and reso values to students. Pacce is a view of life, inspiring compassion for others' suffering and an urge to help. Reso is a view of life encouraging to work hard to get mercy from God. The study involved 332 students from 14 elementary schools in Makassar City, Indonesia and two elementary school teachers. The instruments used in the study were questionnaires, interviews, and observations of learning activities. The results showed that the teachers had made efforts to inherit values that originated from the Bugis-Makassar tribe's wisdom. Efforts were made in the form of teachings, exemplary, and advice, but still incidental without specific planning.
\end{abstract}

Keywords: Value inheritance, pacce (care), reso (hard work), teachings, exemplary, advice Received: $13.11 .2020 \quad$ Accepted: $16.12 .2020 \quad$ Published: 11.01 .2021

\section{INTRODUCTION}

Indonesia's National Medium-Term Development Plan IV (RPJMN IV) for 2020-2024 emphasizes that Indonesia's diverse cultural wealth can be a driving force for the nation and an essential asset for development. All components of the nation need to play an active role in developing the nation's culture and character (Kementerian PPN/Bappenas, 2019). Noble values coming from local wisdom, as part of Indonesia's cultural wealth, need to be preserved and passed on to the younger generation (Elan, Sapriya, \& Abdulkarim, 2018; Azis, Saleh, \& Suriani, 2020). Teachers, as the main education actors in schools, need to play an active role in understanding and passing on local culture, including local tribal wisdom such as pacce and reso values, to shape student attitudes.

Azwar (2013) states that attitude can be formed by various parties, including educational institutions. Cline \& Necochea (1996) suggest that students' attitude in a school environment from various social and cultural groups can be formed through the Effective Character Education Model. The model involves four interrelated dimensions, namely transmission processes, surface manifestations, and the school curriculum, aiming to teach universal core values. Kementerian Pendidikan Nasional (2010) suggests that character building can be conducted through four strategies: strengthening, intervention, modeling, and habituation. Meanwhile, Lickona (1991) divides three components of character formation: moral knowing, moral feeling, and moral action.

In 2010, Badan Pusat Statistik (2011) recorded as many as 1340 ethnic groups in Indonesia. Besides having different customs, tribal ceremonies, languages, traditional houses, and clothing, those ethnic groups also have a life philosophy passed down from generation to generation. Although some of these tribes' cultures have been eroded by globalization, much can be preserved. The Bugis-Makassar tribe is one of the largest ethnic groups in terms of population. The majority of these tribes live in South Sulawesi Province (Badan Pusat Statistik, 2011). The Bugis-Makassar tribe holds siri' na pacce philosophy containing noble values, including pacce and reso (Mattulada, 1975; Umar, 2017).

Pacce is a view of life that causes pain to see others' suffering and encourages assisting (Darwis \& Dilo, 2012; Elvira, 2014; Umar, 2017). Pacce contains love, compassion, empathy, self-sacrifice, and solidarity leading to caring for others (Marzuki, 1995; Ali, 2010; Farid 2017). Meanwhile, reso can be defined as hard work and persistence to achieve goals. The pappaseng is a message passed down from generation to generation in the Bugis culture. "Resopa temmangingngi na malomo naletei pammase dewata" (working hard will make it easier to get the mercy from God) is a familiar pappaseng associated with reso (Umar, 2017; Widiansyah \& Hamsah, 2018; Salim, Salik, \& Wekke, 2018). This message implies that success is not a direct impact of one's hard work, but the consequence of God's love for humans who 
really try. The Bugis-Makassar philosophy is very closely related to the attitude of submission and surrender to God.

This study aimed to reveal the form of activities the teachers undertake in inheriting pacce (caring) and reso (working hard) values to students. Apart from educating students to care and work hard, the teachers also introduced these values as part of the Bugis-Makassar tribe's wisdom. Indirectly, teachers helped to preserve the culture of the Bugis-Makassar tribe.

\section{METHODS}

This research was conducted to obtain an overview of the Bugis-Makassar tribe's cultural inheritance by the teachers in elementary schools. Cultural heritage was devoted to the values of pacce and reso. Researchers focused on observing teacher activities, which were reinforced by teacher statements and student views. The research data were in the form of activities and sentences from teachers and students. Thus this research was qualitative research with a case study approach (Creswell, 2012).

\section{Participants}

The participants in the study came from 14 elementary schools in Makassar City, Indonesia. A total of 332 students comprised of 159 fourth-grade, 89 fifth-grade, and 84 sixth-grade students became respondents in this study. They filled out a questionnaire about the inheritance of pacce and reso values in their school. Furthermore, observation of the learning process and interviews were carried out by two teachers from different schools. Each teacher was given the initials S1 and S2. S1 was female with ten years of teaching experience and S2 was male with six years of teaching experience. Both were from the Bugis-Makassar tribe.

\section{Instruments and Data Collection Process}

The data in this study were obtained using questionnaires, instructional video recordings, and recorded interviews. Researchers had obtained permission from the local education office and school principals to distribute questionnaires to students, record learning activities, and interview teachers.

The questionnaire was given to students via online medium through their respective teachers. The purpose of giving a questionnaire was to discover what students thought about the teacher's activities regarding pacce and reso values inheritance. The questionnaire was consulted with a teacher educator and two elementary school teachers. The questionnaire was also tested on three fourth-grade elementary school students. The trial was conducted to obtain input regarding the clarity of the statements used based on elementary school students' point of view.

Two teachers observed in this study had expressed their willingness and had obtained permission from the principal. Each teacher recorded two meetings with a duration of $2 \times 35$ minutes. After the recording process of learning activities, interviews were conducted to obtain more in-depth information about the activities that had been carried out by the teachers.

\section{Data Analysis}

The data analysis process included data condensation, data presentation, and drawing conclusions and data verification (Creswell, 2012; Miles, 2014). Researchers transcribed recorded lessons and interviews. The transcripts were scrutinized repeatedly in order to be able to encode data and produce descriptive categories. An encoder outside the research team assisted the coding process. Furthermore, the data were presented in graphical form. The data verification process was carried out through the triangulation of methods and member checking (Miles, 2014).

\section{RESULTS}

\section{Students' Opinions Regarding Teachers' Activities in Inheriting Pacce and Reso Values}

The questionnaire results showed that from 332 respondents, only 26 students stated that their teachers had never explained pacce and 44 students stated that their teachers had never explained about reso as part of the Bugis-Makassar ethnic culture. It indicated the pacce and reso values had been conveyed to students in the schools that were the focus of this study. Figure 1 presents the results of a questionnaire regarding the inheritance of pacce and reso values in the form of teachings. 


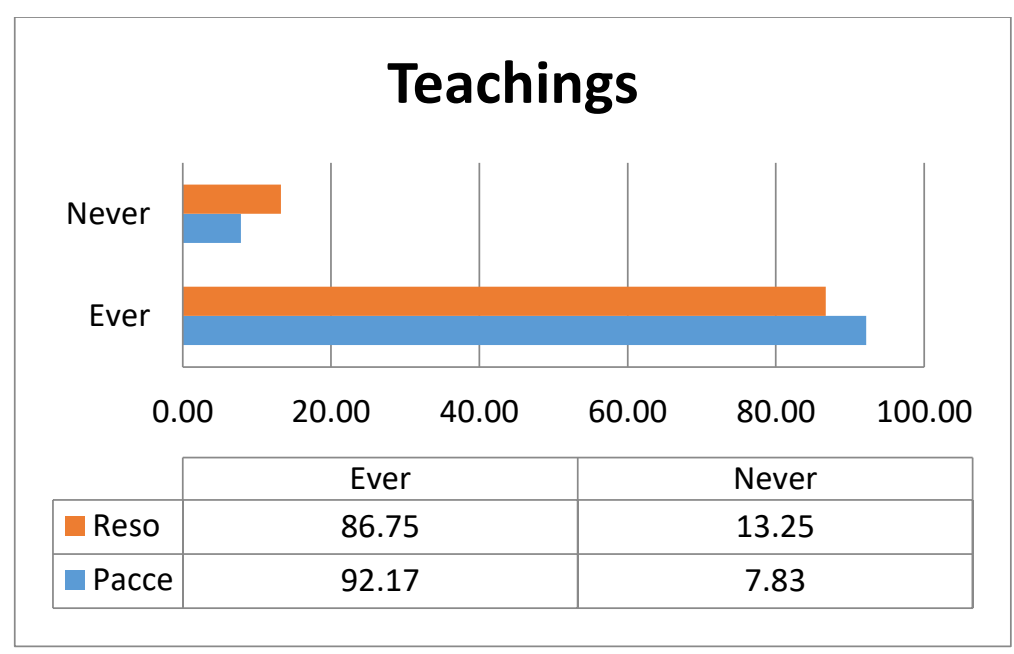

Figure 1. The inheritance of values in the form of teachings

The exemplary form of pacce values was shown by the teacher's caring attitude towards others and the environment. Examples of caring attitudes raised in the questionnaire included the teacher helping others, encouraging students to learn, and being involved in class cleaning activities. As many as $92.57 \%$ of respondents stated that their teachers always showed exemplary caring attitudes. The exemplary form of reso value was shown by the seriousness of completing assignments or teaching. As many as $98.19 \%$ of respondents stated that their teachers always exemplified their sincerity at work. Figure 2 presents the questionnaire results regarding the inheritance of pacce and reso values in the exemplary form.

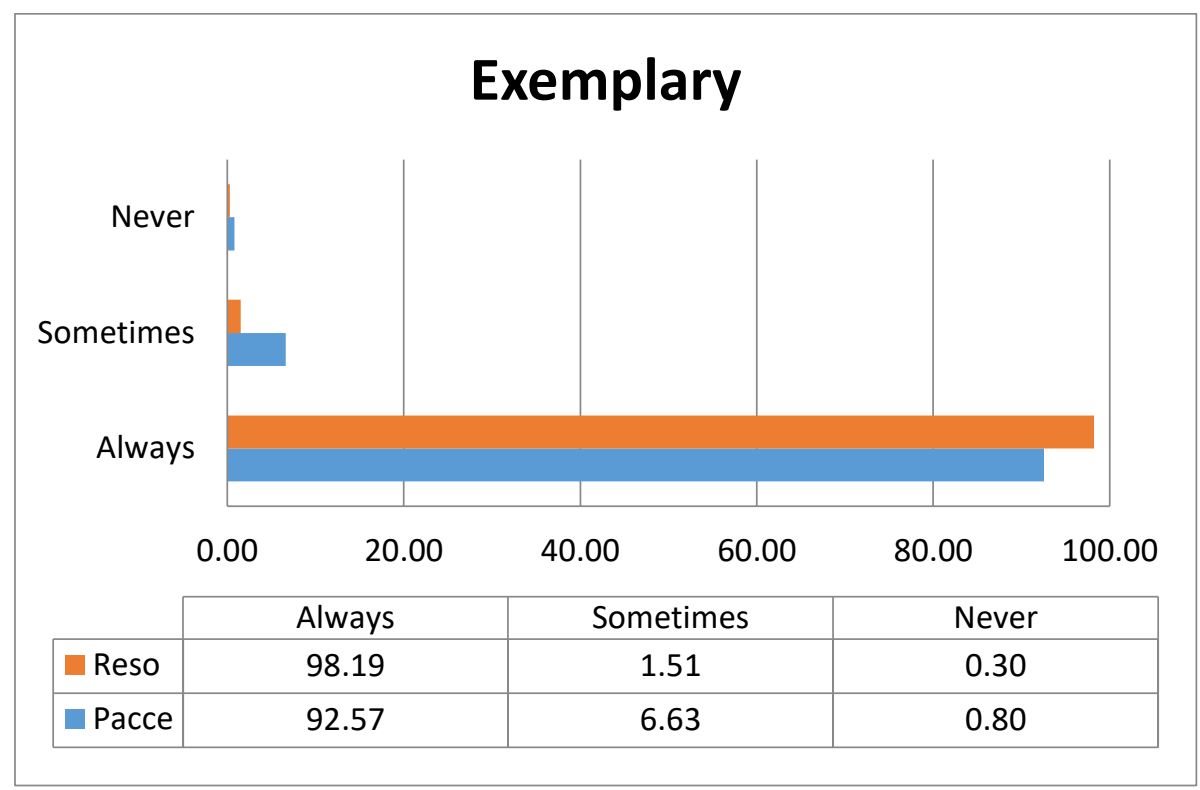

Figure 2. The inheritance of value in the form of exemplary

Value inheritance could be done through advice to take the right action or not to do something bad. The form of the advice pacce value stated in the questionnaire was that the teacher invited students to help and encourage friends. Also, the teacher asked students to clean and tidy up the class. As many as $96.59 \%$ of respondents stated that their teachers always recommended taking actions indicating the value of pacce. The recommended form of reso value was that the teacher asked students to study diligently, not give up quickly, and prohibit copying a friend's work or cheating. As many as $97.19 \%$ of respondents stated that their teachers always recommended taking actions indicating the reso value. Figure 3 presents the results of a questionnaire regarding the inheritance of pacce and reso values in the form of advice. 


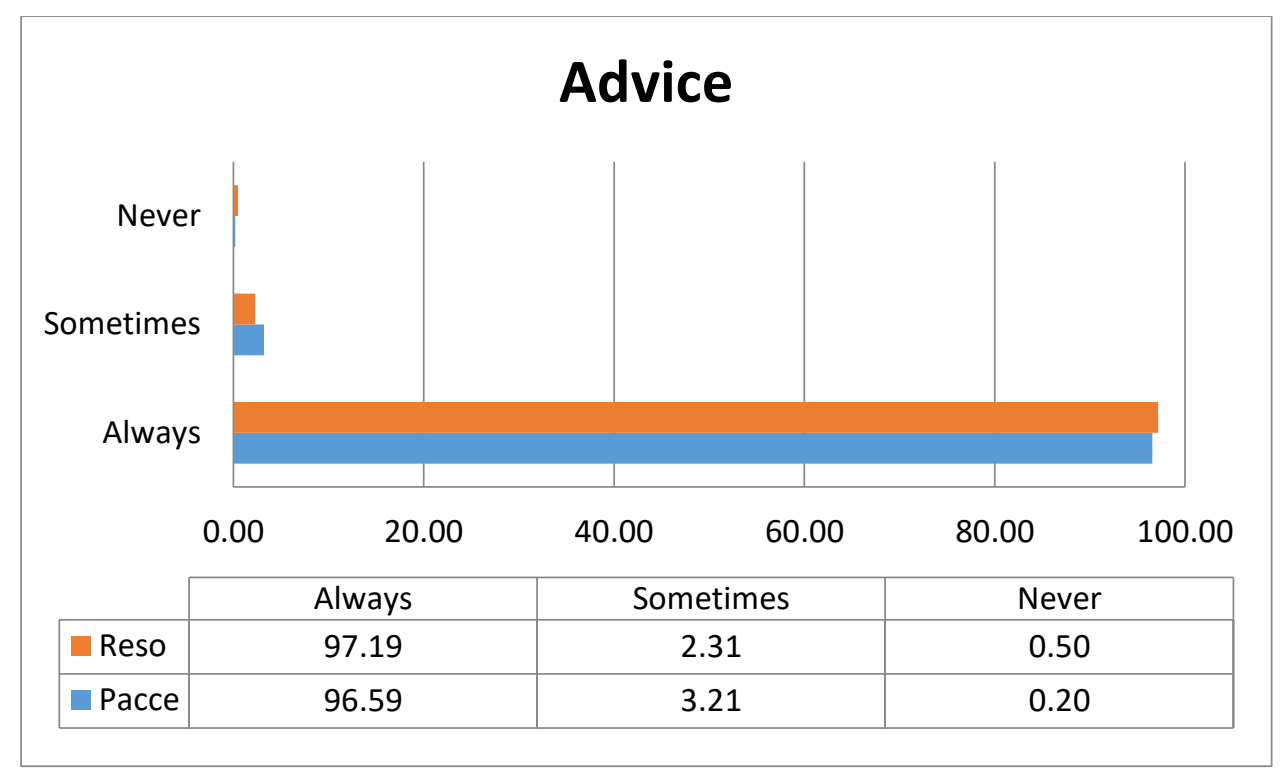

Figure 3. The inheritance of value in the form of advice

\section{Teachers' Activities in Inheriting Pacce and Reso Values}

S1 did the inheritance of pacce and reso in the form of exemplary more than teachings or advice. Figure 4 presents the intensity of teaching, exemplary, and advice for pacce and reso values based on observations of learning activities carried out by S1.
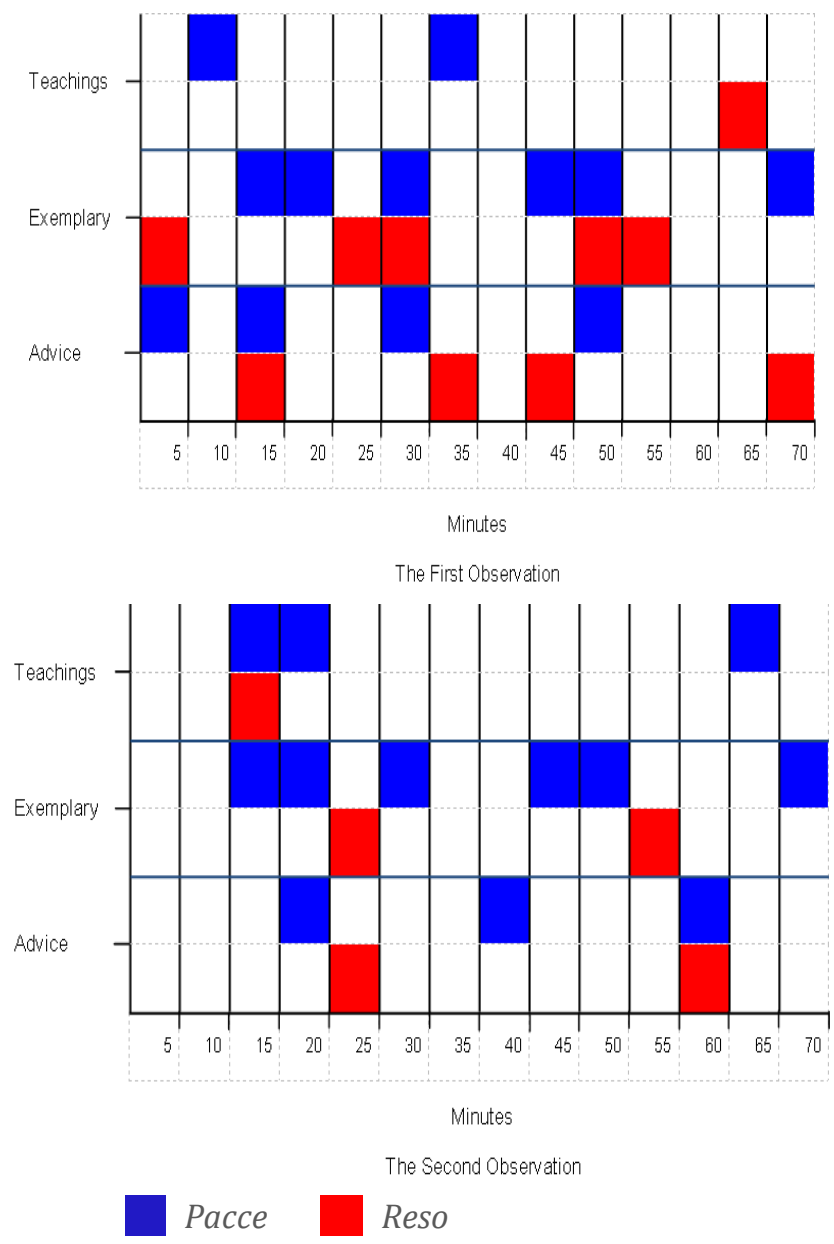

Figure 4. The inheritance of value by $S 1$ 
At the two observed meetings, S1 did not explicitly explain pacce and reso as part of the BugisMakassar tribe culture. S1 described pacce and reso in a universal form, namely caring and hard work. In the first observation, after literacy activities, S1 asked students to return the books they had read to the class's corner. The teacher explained the importance of caring for class cleanliness and tidiness. Not only explaining and advising, but S1 also maintained the classroom environment to look neat and clean. For example, after the activity of pasting an action picture reflecting the Pancasila principles (the philosophy of the Republic of Indonesia), many paper cutouts were scattered on the floor. S1 picked up the paper cutouts and throwing them in the trash. During the pasting activity, S1 occasionally helped students who had difficulty cutting or pasting pictures.

When completing group assignments, S1 encouraged students to be enthusiastic about completing the task and not give up. S1 reminded the students to work hand in hand in completing group assignments, but not to cheat on other groups' work. During class presentations, S1 accompanied the group to make the presentation to motivate and ensure that they could perform well. It exemplified the supportive, motivating, and helpful attitudes of others that are part of the value of pacce. At the end of the lesson, S1 directed students to conclude the subject matter about the meaning of Pancasila principles. S1 explained that in order to achieve their goals, students might study seriously.

At the beginning of the second observation of S1's lesson, a short film about Asmaul Husnah (the names of Allah) was shown. After the screening of the film, S1 explained that God was merciful, therefore humans as God's creatures might also love one another. Students had to love and show concern for friends, for example, by helping to lend stationery or sharing food with friends in need. Like in the first observation, S1 always reminded students to be serious and work hand in hand to complete the task. S1 also reminded the students to keep the class clean. Besides reminding, S1 also exemplified concern for others and the environment.

Of the 19 S1's students filling out the questionnaire, the majority stated that their teacher had taught them about caring and hard work. The majority of them also stated that their teacher always set an example and encouraged them to care and work hard. In the interview session, S1 argued that cultural inheritance was not written in the Lesson Plan. The inheritance of values originating from local culture was carried out if the material taught could be associated with the values.

The inheritance of pacce and reso in the form of teachings was more dominant in S2's lessons than exemplary or advice. Figure 5 presents the intensity of teaching, exemplary, advice for pacce and reso values based on observations of learning activities carried out by S2.
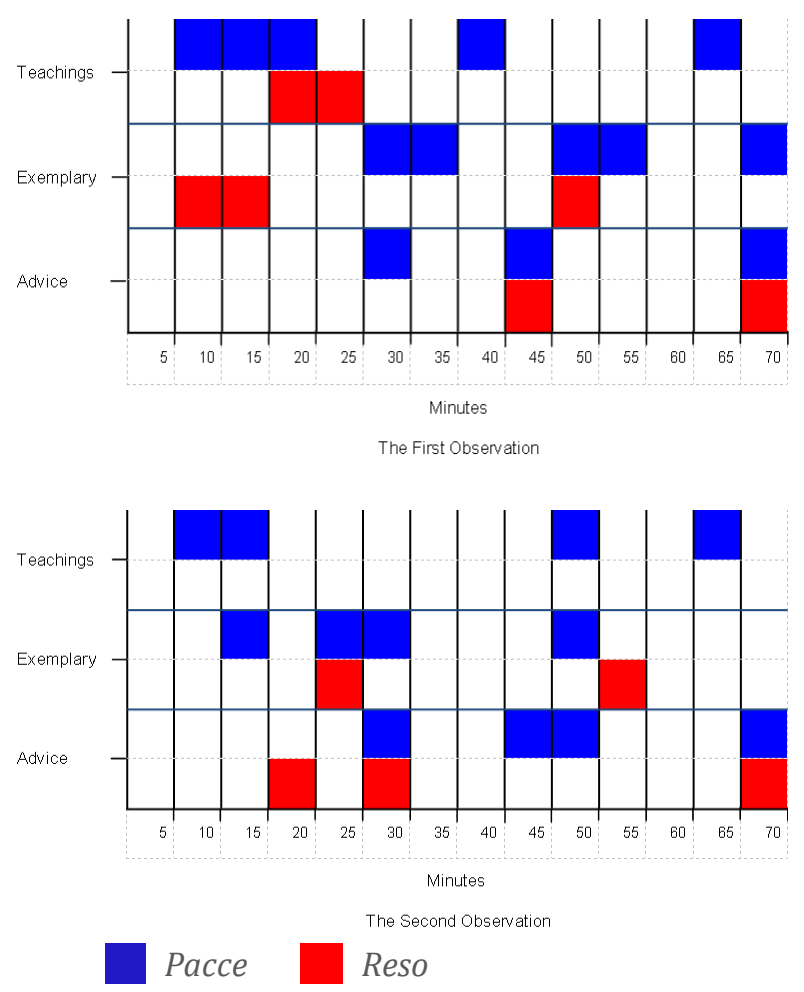

Figure 5. The inheritance of value by $S 2$ 
In the first observation, S2 explained about the third principle of Pancasila: the Indonesian Unity. S2 explained that students had to maintain unity by maintaining good relationships with classmates. Students were supposed to help each other and should not be hostile or fight. S2 also related his explanation with siri' na pacce' (self-respect and care) as the philosophy of life of the Bugis-Makassar tribe. S2 argued that students had to feel ashamed of themselves if they saw other people in trouble, but they did not help if they were actually able to assist. S2 also reminded students to have a sense of pacce towards parents, who had tried hard so that their children could go to school well. Students should show gratitude by being sincere in their studies. In the interview session, S2 revealed that the majority of students came from middle-low income families. Many of them did not have permanent jobs, working as daily laborers, or doing manual labor.

In the middle of the lesson, a student was shaking his chair until he fell. S2 immediately helped the student to fix the position of his chair. It was an example of an exemplary caring attitude towards helping others shown by S2. After giving individual assignments to students, S2 went around the class to help students in trouble. S2 also reminded students to complete their assignments seriously. At the end of the lesson, S2 showed a short film about siri' na pacce. After the film screening, S2 again explained the importance of students having self-esteem and a caring attitude towards others.

In the second observation, S2 explained again about siri' na pacce. After giving students assignments, S2 emphasized the students to try to complete the assignments and not cheat. At the end of learning, S2 reminded students to be diligent in reading, so that their knowledge would be more comprehensive. S2 used a lot of Makassar local language terms.

The results of the interviews revealed that the majority of the students are the Bugis-Makassar tribe. The languages used in the community are Indonesian and Makassarese, so even students who did not have a Makassar ethnicity could mostly understand the local language. S2 also stated that he always tried to link the subject matter with the noble values of the Bugis-Makassar tribe because he was concerned about the lack of student knowledge about the culture of the Bugis-Makassar tribe and the erosion of positive habits. For example, many students did not do mattabe' if they passed in front of the elders. Mattabe' is a way of walking by bending the body and crossing the right arms when walking in front of the elders. However, S2 admitted that the teachings was still done spontaneously, it had not been included in the Lesson Plan. Of the 22 S2's students filling out the questionnaire, the majority stated that their teacher had taught them about caring and hard work. The majority of them also stated that their teacher always set an example and encouraged them to care and work hard.

\section{DISCUSSION AND CONCLUSIONS}

The two teachers who were the focus of this study agreed on the need for the inheritance of noble values originated from local wisdom such as pacce and reso. Even so, their efforts were still incidental, not well planned from the beginning. In line with Azis, Saleh, \& Suriani (2020), the teachers believed the need to instill the value of siri' na pacce in students but had not done it in a planned manner. The form of value inheritance carried out by the teachers was in the form of teachings, exemplary, and advice.

The form of teachings was delivering the meaning and importance of pacce and reso values or in a universal form of caring and hard work. The delivery was associated with the subject matter being taught or spontaneous events occurring in class. The form of teachings could be made more planned, for example, by integrating the values in reading material that would be given to students. Besides that, learning activities could also be planned that were aimed at bringing out certain attitudes. Francis \& Hadisantosa (2017) have tried to integrate respect for others in English teaching materials and learning activities, specifically for street children. These efforts have shown positive results.

In addition to conveying pacce and reso values, the teachers also exemplified these values in attitude during the learning process. Although exemplary is one of the four character-building strategies put forward by the Kementerian Pendidikan Nasional (2010), there are particular problems in its application. Only a few students can recognize the values exemplified and make their teachers a role model (Sanderse 2013; Chowdhury, 2018). Therefore, teachers need to plan well what values will be exemplified and what methods need to be used to be aware and imitate by students.

During the learning process, the teacher also advised students to do or not to do something. Just like teachings and exemplary, advice was carried out incidentally. The advice was sometimes followed by the teachings that argued why something could or could not be done.

The inheritance of values, especially pacce and reso, can be carried out by teachers in a more planned manner by preparing teaching materials to integrate these values or designing activities that allow these values to emerge. Culture-based learning is not just conveying information about the culture and its manifestations, but using culture to support students to gain in-depth knowledge of the material 
they are learning (Komalasari, Abdulkarim, \& Saripudin, 2018). The design of a learning model as an effort to pass on noble values that come from local wisdom can make learning more planned and systematic. It is certainly expected to give better results than incidental value inheritance.

Two teachers who were the focus of this research had made efforts to inherit good attitudes coming from local wisdom, especially the Bugis-Makassar tribe. The efforts made were in the form of teachings, exemplary, and advice, but they were still incidental. Teachers believed in the importance of their inheritance efforts but had not made any specific plans for such efforts. A learning model integrating the introduction of local culture and students' habituation is needed to carry out good attitudes coming from local wisdom. Further research can be carried out by exploring values other than pacce and reso, and developing appropriate learning models.

\section{ACKNOWLEDGMENT}

The research is part of a grant from the Ministry of Research and Technology/National Research and Innovation Agency of the Republic of Indonesia. The authors would like to express sincere appreciation for the support provided.

\section{REFERENCES}

Ali, M. (2010). Kelong dalam perspektif hermeneutika [Kelong in the hermeneutic perspective]. Bahasa dan Seni: Jurnal Bahasa, Sastra, Seni, dan Pengajarannya, 38(1). http://journal2.um.ac.id.

Azis, A., Saleh, S. F., \& Suriani, A. I. (2020). Inculcating siri' na pacce value in primary school learning. Mimbar Sekolah Dasar, 7(1).

Azwar, S. (2013). Sikap manusia: Teori dan pengukurannya [The human attitude: The theory and the measurement]. Yogyakarta: Pustaka Pelajar.

Badan Pusat Statistik [Central Bureau of Statistics Republic of Indonesia]. (2011). Kewarganegaraan, suku bangsa, agama, dan bahasa sehari-hari penduduk Indonesia: Hasil sensus penduduk 2010 [Indonesian citizenship, ethnicity, religion, and colloquial language: Results of the 2010 population census]. Jakarta: BPS.

Chowdhury, M. (2018). Emphasizing morals, values, ethics, and character education in science education and science teaching. MOJES: Malaysian Online Journal of Educational Sciences, 4(2), 1-16.

Cline, Z., \& Necochea, J. (1996). An effective character education model for a diverse student popuplation. The Educational Forum, 60(2), 165-173. doi: 10.1080/00131729609335119.

Creswell, J. W. (2012). Educational research: Planning, conducting, and evaluating quantitative and qualitative research (4th ed). Boston: Pearson Education, Inc.

Darwis, R., \& Dilo, A. U. (2012). Implikasi falsafah siri' na pacce pada masyarakat suku Makassar di Kabupaten Gowa [The implication of siri' na pacce philosophy on the Makassar tribe community in Gowa Regency]. EL HARAKAH Jurnal Budaya Islam, 14(2), 186-225.

Elan, E., Sapriya, S., \& Abdulkarim, A. (2018, November). "Development of values transformation modes of local wisdom of Baduy culture to form student character through civic learning in elementary school: A study of attitude of elementary school students in Kasepuhan Citorek Adat Area, Lebak Regency, Banten Province". Paper presented at the Annual Civic Education Conference (ACEC 2018). Atlantis Press.

Elvira, R. (2014). Ingkar janji atas kesepakatan uang belanja (uang panai') dalam perkawinan suku Bugis Makassar [Broken promise of the shopping money deal (panai' money) in the Bugis Makassar tribe marriage]. Universitas Hasanuddin.

Farid, Z. A. (2017). Siri', pesse', were' pandangan hidup orang Bugis [Siri', pesse', were' the Buginese way of life]. In Hamid, A., et. al. (Eds.). Siri: Filosofis suku Bugis, Makassar, Toraja, Mandar (p. 15-64). Makassar: Arus Timur.

Francis, A., \& Hadisantosa, N. (2017). Elevating respect for others through English lesson. Jurnal Perkotaan, 9, 35-37. doi: 10.25170/perkotaan.v9i1.284.

Kementerian Pendidikan Nasional [Ministry of National Education Republic of Indonesia]. (2010). Kerangka acuan pendidikan karakter tahun anggaran 2010 [The reference terms for character education for the 2010 fiscal year]. Jakarta: Kementerian Pendidikan Nasional.

Kementerian PPN/ Bappenas [Ministry of National Development Planning/Bappenas Republic of Indonesia]. (2019). Rancangan teknokratik rencana pembangunan jangka menengah nasional 2020-2024: Indonesia berpenghasilan menengah - tinggi yang sejahtera, adil, dan berkesinambungan [Technocratic draft national medium-term development plan 2020-2024: 
Prosperous, fair, and sustainable middle-high-income Indonesia]. Jakarta: Kementerian PPN/ Bappenas.

Komalasari, K., Abdulkarim, A., \& Saripudin, D. (2018). Culture-based social studies learning model in developing student multiculturalism. The New Educational Review, 51(1), 173-183. doi: 10.15804/tner.2018.51.1.14.

Lickona. T. (1991). Educating for character: How our schools can teach respect and responsibility. New York.

Marzuki, M., L. (1995). Siri': Bagian kesadaran hukum rakyat Bugis-Makassar: Sebuah telaah filsafat hukum [Siri': The Bugis-Makassar legal awareness section: An analysis of legal philosophy]. Ujung Pandang: Hasanuddin University Press.

Mattulada. (1975). Latoa: Satu lukisan analitis terhadap antropologi-politik orang Bugis [Latoa: A descriptive analysis of the Buginese political anthropology]. (Unpublished dictoral's dissertation). Jakarta: Universitas Indonesia.

Miles, M. B., Huberman, A. M., \& Saldaña, J. (2014). Qualitative data analysis: A methods sourcebook (3rd ed). United Kingdom: SAGE Publications, Inc.

Salim, A., Salik, Y., \& Wekke, I. S. (2018). Pendidikan karakter dalam masyarakat Bugis [Character education in the Bugis society]. Ijtimaiyya: Jurnal Pengembangan Masyarakat Islam, 11(1), 41-62.

Sanderse, W. (2013). The meaning of role modelling in moral and character education. Journal of Moral Education, 42(1), 28-42.

Umar, N. F. (2017). Pengembangan model kepribadian konselor efektif berbasis budaya siri' na pesse [The development of an effective counselor personality model based on siri' na pesse culture]. Indonesian Journal of Educational Studies, 20(1). doi: https://doi.org/10.26858/ijes.v20i1.4425.

Widiansyah, S., \& Hamsah, H. (2018). Dampak perubahan global terhadap nilai-nilai budaya lokal dan nasional [The impact of global changes on local and national cultural values]. Hermeneutika: Jurnal Hermeneutika, 4(1), 39-48. 